\title{
Factory Manager Bypasses Lockout/Tag-out and is Electrocuted
}

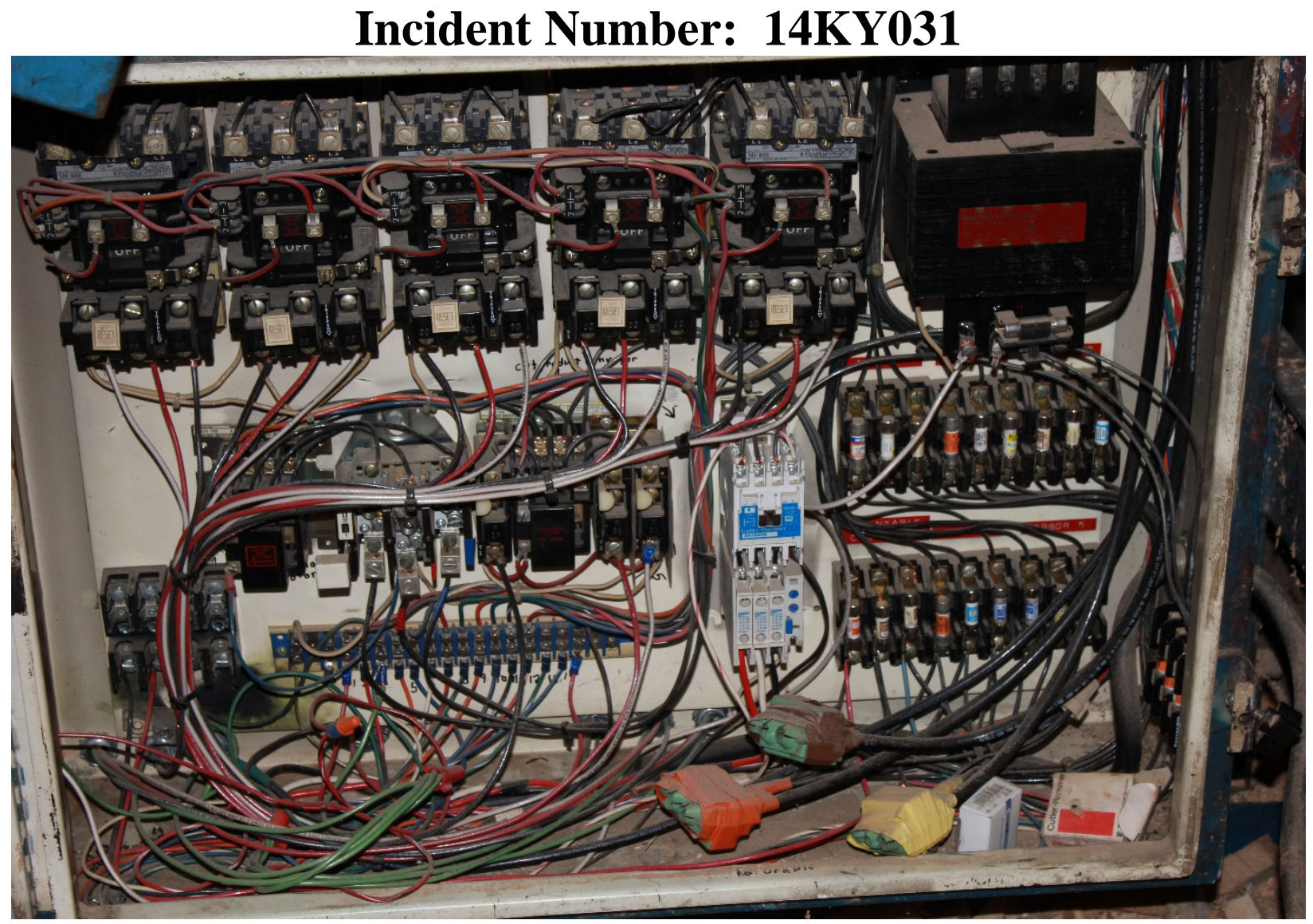

Control panel box of multiple blade saw

Photo courtesy of KY OSHA

Kentucky Fatality Assessment and Control Evaluation Program Kentucky Injury Prevention and Research Center 333 Waller Avenue

Suite 242

Lexington, Kentucky 40504

Phone: 859-323-2981

Fax: 859-257-3909

www.kiprc.uky.edu

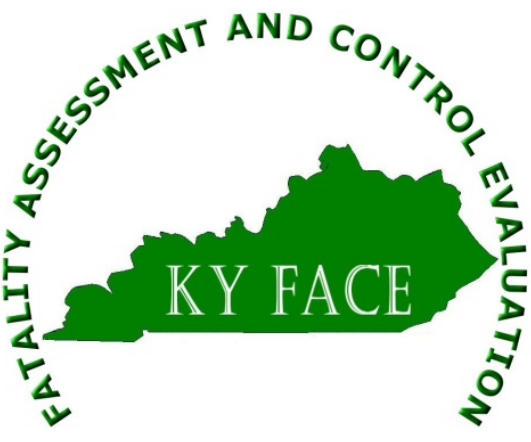




\section{Kentucky Fatality Assessment and Control Evaluation (FACE) Program Incident Number: 14KY031 Release Date: October 17, 2014 Subject: Factory Manager Bypasses Lockout/Tag-out and is Electrocuted}

\section{Introduction}

On June 11, 2014, a 37-year-old factory manager and married father of three was called to check on a 5 blade multiple trim saw. Two employees reported that the saw was not working properly. The victim walked to the electrical panel box and failed to de-energize the saw by properly shutting down any hazardous energy. He did not lockout, tag-out, and verify hazardous energy shut down before servicing the saw. The victim reached into the energized electrical panel box to reset a relay and came into contact with 480 volts of electricity. This shock was powerful enough to send him into cardiac arrest. The employees who were working on the saw immediately turned around and discovered the victim lying unconscious on the ground. One employee called 911 at 11:45 am, while the other employee performed CPR. EMS arrived at 11:56 am and the victim was transported to the local hospital, where he was pronounced dead.

To prevent future occurrences of similar incidents, the following recommendations have been made:

Recommendation No. 1: Employers should ensure that all employees servicing or maintaining electrical equipment practice proper lockout/tag-out (LOTO) procedures.

Recommendation No. 2: Employers should ensure that management is leading by example by following all safety policies.

\section{Employer}

The employer was a woodworking company that cut saw mill lumber into specific lengths to produce pallets per customer requests. The business began in January 2013, and had been in business for 18 months at the time of the incident. Seven employees worked at this location including the victim.

\section{Written Safety Programs and Training}

The employer had all the OSHA required written safety training programs and provided worker safety training to their employees. Lockout/Tag-out (LOTO) training had been provided by an outside vendor to the employees on September 5, 2013.

\section{$\underline{\text { Victim }}$}

The victim was a 37-year-old father of three children, who had been employed with the company for 18 months, and had assisted with company startup. He was a factory manager and held a master's degree. 


\section{Incident Scene}

The incident occurred inside a fabricated metal building. The victim was by the control box of a five blade multiple trim saw. The saw was manufactured by Cornell Manufacturing, Inc. and was a model MSTB, Serial \#294-4-86.

\section{$\underline{\text { Weather }}$}

June 11, 2014, was an overcast day with temperatures ranging from 71 to 78 degrees Fahrenheit. Weather did not appear to be a factor in the fatality.

\section{Investigation}

On June 11, 2014, the Kentucky Fatality Assessment and Control Evaluation Program was notified by the Kentucky Labor Cabinet of an occupational fatality involving a factory manager. A 37-year-old factory manager and married father of three was called to check on a five blade multiple trim saw, Model MSTB, Serial \#294-4-86, manufactured by Cornell Manufacturing, Inc. Two employees had reported the saw was not working properly. The victim walked over to the electrical panel box for the saw but did not properly de-energize it by shutting down any hazardous energy. He did not lockout, tag-out, and verify hazardous energy shut down. The victim reached into the energized electrical panel box to reset a relay and came into contact with 480 volts of electricity, causing him to go into cardiac arrest. The employees who were working on the saw immediately turned around and discovered the victim lying unconscious on the ground. One employee called 911 at 11:45 am, while the other employee performed CPR. EMS arrived at 11:56 am and the victim was transported to the local hospital, where he was pronounced dead by the emergency department physician.

The Department of Housing, Buildings and Construction Electrical Division was contacted by the Fire Marshall, who requested an electrical inspection of the incident scene. An investigation was opened on June 13, 2014. The inspector spoke with employees, who reported seeing the victim bend down in front of the open door of the machine control panel without first deenergizing it. The saw was fed from panel A, and protected by a $100 \mathrm{amp} 3$ pole breaker. The conduit and wiring from the main electrical panel to a $100 \mathrm{amp}$ rated 3 pole was traced. The inspector found no electrical violations or concerns with equipment or wiring. He concluded that faulty equipment or wiring was not to blame for the incident that occurred.

\section{Cause of Death}

The cause of death was low voltage electrocution.

\section{$\underline{\text { Recommendations and Discussions }}$}

Recommendation No. 1: Employers should ensure that all employees servicing or maintaining electrical equipment practice proper lockout/tag-out (LOTO) procedures. 
The employer had a LOTO policy and procedures, and employees had been trained by an outside contractor on September 5, 2013. The victim had attended this training, and was aware of the hazards, but safety procedures were not followed and he reached inside the control panel, resulting in electrocution. The OSHA standard for LOTO actions and procedures can be found in 29 CFR 1910.147. "This standard covers the servicing and maintenance of machines and equipment in which the unexpected energization or startup of the machines or equipment, or release of stored energy could cause injury to employees. This standard establishes minimum performance requirements for the control of such hazardous energy."

Recommendation No. 2: Employers should ensure that management is leading by example and following all safety policies.

Managers should be held to the same worker safety standards as employees, and should lead by example. If management is not leading by example, employees may not follow required worker safety policies, which could put them at risk for injury or death.

Keywords

Electrocution

Lockout/Tag-out

De-energizing electric

Shock hazards

Hazardous energy

\section{References}

http://www.osha.gov/SLTC/controlhazardousenergy/otherresources.html

http://www.asse.org/practicespecialties/

https://www.osha.gov/pls/oshaweb/owadisp.show_document?p_table=STANDARDS\&p_id=980 $\underline{4}$

http://www.cdc.gov/niosh/docs/wp-solutions/2011-156/pdfs/2011-156.pdf

\section{Acknowledgements}

The Kentucky FACE program would like to thank the KY OSHA, the coroner, and the Public Protection Cabinet for their assistance with this report.

The Kentucky Fatality Assessment \& Control Evaluation Program (FACE) is funded by grant 2U600H008483-10 from the Centers for Disease Control and Prevention and the National Institute for Occupational Safety and Health. The purpose of FACE is to aid in the research and prevention of occupational fatalities by evaluating events leading to, during, and after a work related fatality. Recommendations are made to help employers and employees have a safer work environment. For more information about FACE and KIPRC, please visit our website: www.kiprc.uky.edu 


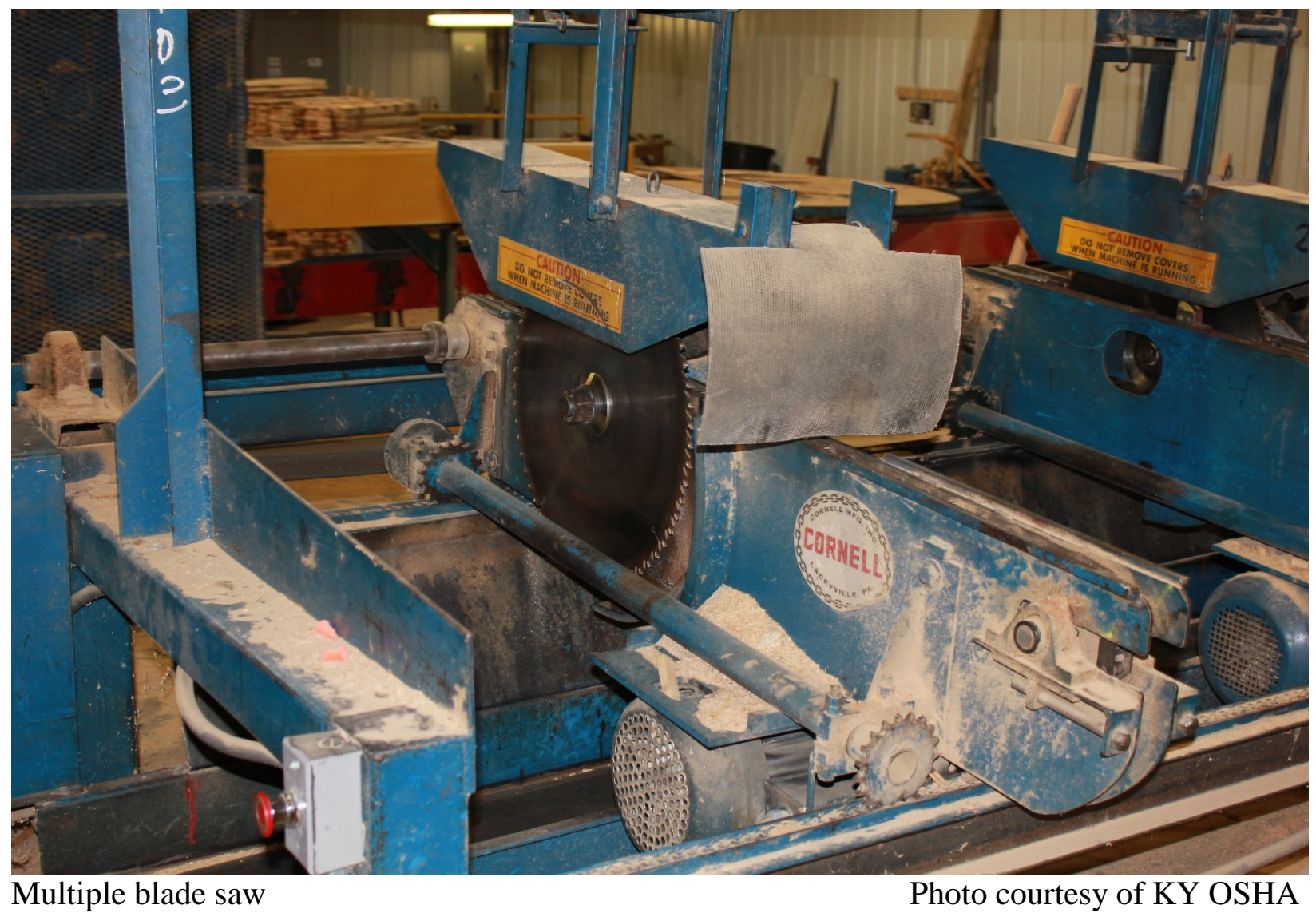




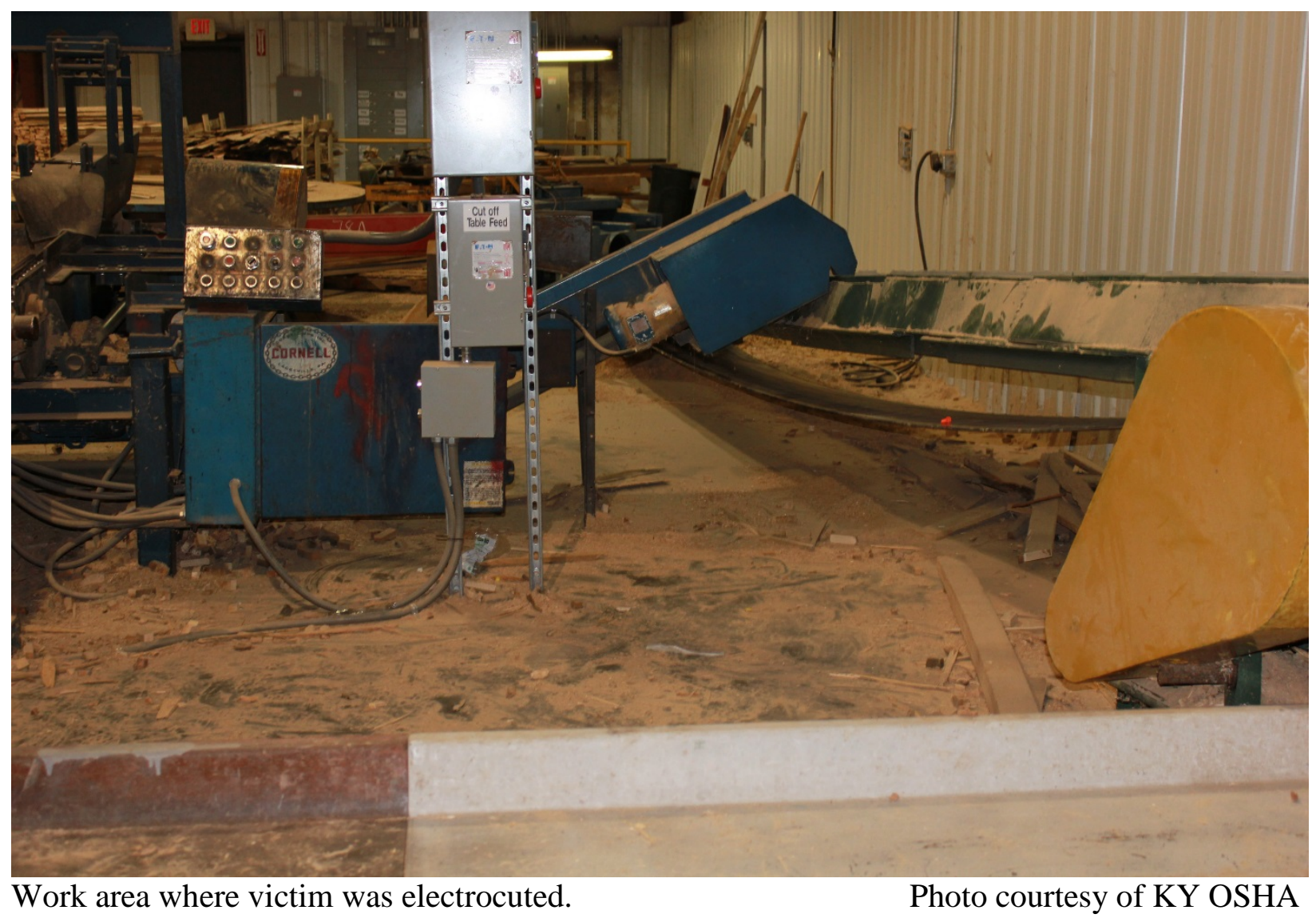

